\title{
Instruction Dialogues in the Zhuangzi: An "Anthropological" Reading
}

\author{
Carine Defoort
}

Published online: 20 October 2012

(C) Springer Science+Business Media Dordrecht 2012

\begin{abstract}
There is a tendency in academia to read early Chinese masters as consistent philosophers. This is to some extent caused by the specific form in which these masters have been studied and taught for more than a century. Convinced of the influence that the form of transmission has on the content, this article studies the more fragmented parts of the book Zhuangzi-instruction scenes or dialogues - and more specifically their formal traits rather than the philosophical content conveyed in them. The focus is on one fragment in Chapter 7 which portrays Liezi, a shaman and Master Calabash. The persons and stages of the instructions scenes in the Zhuangzi seem to promote a non-teaching, in which the learner learns while the teacher does not teach. The non-availability of the teacher and his unwillingness to teach are, paradoxically, at the core of the teaching, although not presented as a valuable alternative.
\end{abstract}

Keywords Zhuangzi Anthropology Instruction · Masters · Formal characteristics

\section{Masters of Chinese Medicine}

When Elisabeth Hsu wanted to learn about Chinese medicine, she did what our students often do: go to China. Thus she found herself studying at the Yunnan Traditional Medicine College in Kunming, where students armed with standard textbooks received objective, theoretical, scientific explanations during lectures, took part in clinical courses to gain experience, and finally were tested on their knowledge and skills by means of exams. But at Hsu's insistent requests about wanting to learn "real" Chinese medicine, some colleagues at the college introduced her to a senior Chinese doctor, named Zhang, who apparently taught the same subject differently: at his home, together with a select group of disciples, on the basis of a few classical texts that were to be committed to memory, with more emphasis on interpretation and

Carine Defoort $(\bowtie)$

Department of Sinology, University of Leuven, PO Box 3318, 3000 Leuven, Belgium

e-mail: Carine.Defoort@arts.kuleuven.be 
experience than on theoretical coherence, and of course without any official exam or diploma. Hsu benefited from this home-taught class, even though she occasionally was baffled when the master ignored her questions, enunciated a wise saying, or launched into a self-important rant, before returning to the text. Hsu also discovered a third form of transmitting Chinese medicine, when she was strolling by bike through a back alley, and found a healer who taught one single pupil by means of memorization and recitation of secret, powerful formulas, imitation of concrete actions, and without any theoretical explanation. Hsu was accepted as a disciple and observer of this method (Hsu 1999: 8-14).

The central idea of her book, The Transmission of Chinese Medicine, is that the content of teaching is inseparable from the teaching method. In these three types of transmission by different masters - respectively the "standardized" teaching of the professor, the "personal" teaching of the scholar, and the "secret" teaching of the healer - one not only learns Chinese medicine in different ways, but one inevitably learns very different things. Hence her interest in the formal aspects of these three types of transmission, such as different approaches to texts, the relationship between experience and theory, the role of master and student, various types of authority, and the general setting of the teaching events. Although Hsu does not claim that this specific research in the city of Kunming is representative of all of Chinese medicine's existing types of transmission, she does show convincingly that form has a strong influence on content: the secret healer could not possibly transmit his knowledge and skills in a university lecture theatre to a crowd of listening students. University education, in turn, carefully maintains its distance from the selective, personal, and therefore unscientific knowledge of the scholar teacher. But the scientific, academic approach conveying the only form of medical knowledge that enjoys the state's backing, is also tied to a particular form of teaching, the most modern and Westerninfluenced of the three, which is not what one might expect from the name Traditional Chinese Medicine (TCM).

Elisabeth Hsu's work has been picked up beyond the field of Chinese medicine. It inspired Joël Thoraval to distinguish different forms of transmission of traditional Chinese thought. In pre-modern China, prior to the large-scale introduction of philosophical discourse, speculative texts were often embedded in a context of practices, such as meditation and breathing exercises, ascetic and moral efforts, painting, dance, or poetry. Writings were usually not self-contained, consistent, theoretical constructions, but rather footnotes to living practices. Before university education was introduced in China, these practices relied upon small-scale, personal forms of transmission, somewhat like that of the learned master or the secret healer studied by Hsu. The current dominance of one single form, namely university education in departments of philosophy, not only threatens this symbolic context with extinction, ${ }^{1}$ but also uproots the speculative texts from the soil in which they used to grow. Thoraval therefore argues in favor of an "anti-philosophical" reading of the Chinese intellectual heritage (Thoraval 2002: 76-79), a radical step that few colleagues have followed. Although often sympathizing with his criticism, many

\footnotetext{
${ }^{1}$ The fate of these symbolic practices is complex: some are found under academic disciplines such as philosophy, religion, or art, where they are studied, preserved and reinvented; some disappear or survive at a popular level. See e.g. Billioud and Thoraval 2007: 4-20, and Billioud and Thoraval 2009: 82-100.
} 
scholars rather challenge the view of philosophy that he presumes: Why should philosophy only be understood in its modern, academic sense? ${ }^{2}$ Michel Foucault, for instance, draws a picture of early Hellenistic and Roman philosophy that is in many ways reminiscent of the practices that Thoraval is trying to salvage.

In a series of lectures on L'herméneutique du sujet Foucault analyzes the history of Western philosophy as a constant tension between the spiritual practices of "care for oneself" or "care of the self" (souci de soi, epimeleia heautou) and the more rational ideal of "knowledge of oneself" (connaissance de soi, gnōti seauton) (Foucault 2001). Although the latter predominates nowadays in academia, Foucault pays particular attention to the practices of "care for oneself" current in the first centuries CE. The philosophies of the Cynics, the Stoics, and the Epicureans that he analyzes form no more coherent, rational whole than pre-modern Chinese thought and must be reconstituted from private letters and loose notes; there is also less interest in theoretical speculation than in practical instructions transforming the practitioner; the counsels are not presented as universal principles but as specific elements of a particular art of living: exercises in concentration, fasting, isolation, retreat, memorization, and so forth. These and many other characteristics do not keep Foucault from speaking of Hellenistic and Roman philosophy. The question of whether ancient Chinese thought can be called "philosophy" is not, however, the point I wish to address here, ${ }^{3}$ but rather the way in which Foucault approaches this body of thought. Like Elisabeth Hsu, he focuses on the form in which ideas and practices grow and are communicated: early Hellenistic and Roman philosophers were often not (or not exclusively) professional teachers, but at the same time friends, politicians, or private advisers; besides lecture notes from schools, ideas were passed on in letters, anthologies of sayings, and no doubt in personal conversation.

Many works of early Chinese masters ( $z i$ 子) could lend themselves to an interpretation such as that of Hsu and Foucault. The coherence of their insights lies not necessarily in theoretical consistency, but rather in the interplay between the sayings and the concrete context, specific practices, or a certain lifestyle. ${ }^{4}$ We can roughly trace an evolution of form in these Masters' texts from wise enunciations and brief dialogues, to quasi-dialogues, and finally monologue treatises or staged dialogues between master and ruler. ${ }^{5}$ The Zhuangzi, a book in 33 chapters named after ZHUANG Zhou and compiled between roughly the 4 th and 2 nd centuries BCE, reflects this evolution. As A.C. Graham points out, the book not only contains "composed essays," which he dates in the third century BCE, but also "jotted down sayings, verses, stories, thoughts," which he considers slightly older (Graham 1986: 27). Despite the unintelligible fuzziness and apparent philosophical inconsistencies of the original text, especially in what is generally considered its older parts, ${ }^{6}$ its current

\footnotetext{
${ }^{2}$ To deny ancient Chinese thought the label of "philosophy" is based on an understanding of what philosophy is and what type of approach to texts it entails. But this very understanding is the object of an unending disagreement. On this debate, see note 3.

${ }^{3}$ Whether or not one chooses to label Zhuangzi a philosopher, his ideas are certainly considered philosophically interesting by many. On this larger debate, see e.g. Defoort 2001 and Defoort 2006.

${ }^{4}$ For a strong statement of this view, see Eno 1990: 1-15.

${ }^{5}$ On this evolution, see e.g. Lewis 1999: 56-57, 60-62; and Fu Sinian 2003: 17-21.

${ }^{6}$ For attempts to reconstruct the chronology of the various Zhuangzi chapters, see e.g. LiU Xiaogan 1994: 171, Roth 1991: 122-123, and McCraw 2010: 87-100.
} 
interpretation is almost exclusively of one type, namely that of academic coherence, as expected in the disciplines of philosophy, history, or sinology. Within these disciplines there remains, of course, room for ongoing debate between a variety of interpretations presenting the putative author as a primitivist, relativist, individualist, hedonist, pessimist, nihilist, fatalist, naturalist, mystical negativist, transcendentalist, evolutionist, pre-Zen Buddhist, cynic, skeptic, contemplative, metaphysician, idealist or materialist, and so forth. In philosophy departments, Zhuangzi generally figures as a worthy counterpart to other respectable philosophers. Such contemporary interpretations tend to favor the relatively coherent essays and disregard or "charitably" reconstruct the textual fragments into a clear presentation of the philosophical content. ${ }^{7}$ It is not my intention to totally reject such interpretations, only to question their virtually exclusive dominance by presenting an "anthropological" (for lack of a better term) reading of the same material. ${ }^{8}$ Inspired by Hsu and Foucault, but without referring further to them, I will look at some Zhuangzi dialogues through the lens of forms of teaching that the work itself offers, and that might open up new insights on its content.

\section{Instruction in the Zhuangzi: Liezi, Calabash, and the Shaman}

What alternative forms of instruction can be found in the Zhuangzi? If we look at Warring States texts in general, the teaching mode undeniably plays an important role. Mark Lewis traced its evolution over two centuries: the oldest parts of the Lunyu, possibly dating from the late 5th or 4th century BCE, contain sayings and dialogues that record-or claim to record-teaching scenes staging Confucius as authoritative teacher; by the 3rd century BCE the teaching scene has become secondary while persuasive arguments carry authority on their own, as in the Hanfeizi. Lewis posits Zhuangzi between these two types: he argues that the book carries no implicit teaching scene and that its authors or editors probably did not form a strong association with teacher-disciple bonds (Lewis 1999: 61-62). ${ }^{9}$

I believe that Zhuangzi's teaching scenes nevertheless contain glimpses of and a vision on early Chinese forms of education. Even though the book is indeed not framed in the teaching mode as is the Lunyu, many instruction stories do express a close familiarity with and deep interest in types of teaching current in those days, about which we, admittedly, know little with certainty. ${ }^{10}$ And even though the authors

\footnotetext{
7 The "principle of charity," named as such in 1958-59 by Neil Wilson and much discussed by philosophers, requires that the reader or listener interpret an author's or speaker's statements as rational, coherent, valid, and interesting. There has been discussion about the possible traps of such an attitude, especially in the interpretation of foreign and unfamiliar cultures. See e.g. Feldman 1998: (vol. 2) 282-285.

${ }^{8}$ For some very different critics of this overly coherent reading of the Zhuangzi, see, e.g. Wu Kuang-ming 1982: 9; Billeter 2004a (Leçons): 128-130; and McCraw 2010: 87-100. These works are inspiring as long as they do not make claim to be the only true interpretation.

${ }^{9}$ For attempts to situate Daoist texts in a concrete group of people sharing specific practices and transmitting texts, see e.g. Roth 1999: 173, 181-85. About the "Laoist" community of alienated idealists, see Michael LaFargue 1992: 190-95. Aside from such intriguing educated guesses, two major reference works on, respectively, Daoism and education in China, have little to say about education in the Zhuangzi: see Kohn 2000 and Lee 2000.

${ }^{10}$ For information on private instruction in Ru and Mohist circles, or practised by physicians and specialists in all sorts of techniques, see e.g. Lloyd and Sivin 2002: 42-46 and Harper 1996: 55-67. For a fascinating attempt to reconstruct the social organization of Confucius in the Analects, see Csikszentmihalyi 2001: 265-273.
} 
themselves were perhaps not much engaged in such relations, they often did choose to simulate or parody them. ${ }^{11}$ These scenes of instruction between "master" and "disciple" - dialogues in which one person asks advice from another-are the subject of this essay, and more specifically one story from chapter 7 engaging three figures. An attempt to focus on these "instruction scenes" implies putting aside monologues, quasi-dialogues, and other dialogues: between friends or strangers, rivals or colleagues, officials and craftsmen. Due to the lack of clear institutional settings and professional teachers in the Zhuangzi, the boundaries between instruction and other scenes are impossible to draw strictly, the greyest zone being between "teaching events" and "audiences" in which the ruler treats his counselor with the reverence due to a teacher. ${ }^{12}$

This article mainly provides an analysis of one instruction scene, namely when Liezi, visits his master Calabash four times with a shaman. In the periphery of this story, I will more furtively touch upon other instruction dialogues in the Zhuangzi. Without postulating one strong thinker, author, or editor behind all these scenes, I will, for the sake of stylistic simplicity, attribute the insights retrieved from them to a hypothetical person named "Zhuangzi."13 The degree of consistency to be found among them is, of course, relative: more practical than theoretical, more aesthetic than logical, and undermining certainties rather than stating them.

The story on which we focus involves a disciple, a shaman, and a master. It appears in the seventh chapter of the Zhuangzi, the last of the Inner Chapters. This dialogue is not among his best-known stories, and my translation is rather literal and sometimes tentative, not only because of textual obscurities, but also because of the somewhat esoteric nature of the instructions. ${ }^{14}$

In the state of Zheng there was a shaman of the spirits called Jixian. He knew people's life and death, ruin and saving, good and bad fortune, long or short life: he could set the date within a year, a month, a week, or a day, as though he himself was a spirit. As soon as the people of Zheng saw him, they all turned their backs and fled. But when Liezi saw him, his heart was intoxicated. He returned to tell Master Calabash: "Master, once I thought that your Way was the highest, but there is another which is higher still."

\footnotetext{
${ }^{11}$ Perhaps the instruction form was taken for granted as one way to express one's ideas, inherited from sources that did emerge from teacher-disciple associations. For the stylistic idealization of dialogue scenes, see Harper 1996: 42.

${ }^{12}$ According to Lewis, the increase of this more political setting is typical for 3rd century BCE texts. See Lewis 1999: 62-63. However weak the Zhuangzi authors' political aspirations may have been, they share in the fantasy of a king humbly learning from a wise master. The fact that the book often expresses disdain for political authority does not belie this interest.

${ }^{13}$ For various theories on the division of the book, see footnote 6 . On the basis of different rhyming patterns, David McCraw has identified more than a dozen hands in the formation of the Inner Chapters (Chs. 1-7) alone. See McCraw 2010: 47. For his tentative account of the whole book, see McCraw 2010: $87-100$.

${ }^{14}$ Henceforth, references to passages from the Zhuangzi give the chapter in Arabic numerals and the passage in Roman numbers, following the division of fragments in Victor Mair's translation: Wandering on the Way: Early Taoist Tales and Parables of Chuang Tzu. For example, this long fragment is referred to as 7V (fifth fragment in Mair's translation of chapter 7; see Mair 1994: 68-70). For other editions or translations of this fragment, see e.g. Graham 1986: 96-98; HuANG Jinhong 1983: 120-21, 124-25; Watson 1968: 94-97; Levi 2006: 67-68; Billeter 2004b: 31-35 (Etudes).
} 
Master Calabash said: "With you I have touched upon the surface pattern but not yet upon the substance. Have you really grasped the Way? With so many hens but no cock, what eggs can you expect from them? By opposing the Way to the world, you insist on being believed. And therefore you have allowed someone to read your face. Try bringing him here and let him take a look at me."

The next day, Liezi took [the shaman] to see Master Calabash. When they left, the shaman said: "Oh, your Master is going to die. I cannot revive him anymore: his last days are counted. I saw something strange in him: I saw damp ash in him." Liezi went in again, crying and with tears soaking the lapels of his coat. He told Master Calabash, who said: "Just now I showed him the patterns of the earth, like germs not moving but not stopping. He earlier on saw me hold down the trigger of power. Try bringing him around again."

The next day, Liezi took him again to see Master Calabash. When they left, the shaman said: "How lucky that your Master happened to meet me! He is much better: he is brimming with life! I saw him holding down the scales." Liezi went in again and told Master Calabash, who said: "Just now I showed him the heavenly clod, where names and substances do not enter, and the trigger comes up from the heels. He earlier on saw my trigger of the Good. Try bringing him around again."

The next day, Liezi took him again to see Master Calabash. When they left, the shaman said to Liezi: "Since your Master is unstable, I do not get to read his face. If he tries to stabilize, I will return to read his face." Liezi went in and told Master Calabash, who said: "Just now I showed him the supreme vastness where nothing wins out. He earlier on saw me balance the triggers of energy.... ${ }^{15}$ Try bringing him around again."

The next day, Liezi took him again to see Master Calabash. Before he had come to a standstill, the shaman was at a loss and fled. "Run after him," said Master Calabash. Liezi did so, but could not catch up. On his return he reported to Master Calabash: "He has disappeared! He is lost! I could not catch up with him." Master Calabash said: "Just now I showed him my ancestor before I had begun to come out. I was in emptiness intertwined with it, not knowing who is who. Now he thought that I was ebbing away, and then he thought that I was surging up. That is why he fled."

Only then did Liezi believe that he himself had not yet begun to learn. He returned home and did not come out for three years. He cooked for his wife and fed the pigs as though feeding humans. From his work he kept aloof; and from a polished gem he returned to be an un-carved block. In one piece, alone with his body, he stood there. In the midst of entanglement he remained sealed, and in this oneness he ended his life.

\footnotetext{
${ }^{15}$ Like Graham 1986: 97, I take the following line as a possible commentarial intrusion: "Where the swirling waves gather, there is an abyss; where the still waters gather, there is an abyss; where the running waters gather, there is an abyss. The abyss has nine names and I have shown him three."
} 
Primarily on the basis of this long fragment and, only secondarily, using some shorter passages, I will discuss the formal characteristics of Zhuangzi's instruction: the relationship between master and disciple (section 3) and the four main stages of the instruction event (section 4). ${ }^{16}$

\section{Who Is the Master?}

Masters are important in Zhuangzi's teaching scenes: they are not only treated with great reverence, but often function as the topic of conversation: Who is a true master? Who is the best? Who becomes whose disciple? Not infrequently, teaching moments take place in an atmosphere of rivalry, sharpened by the general ambiguity as to who or what is actually the master. The same is true of this fragment. Foretelling the future was a highly valued skill in China. The shaman, with whom Liezi is so taken, does this through the art of physiognomy, an art that was practiced not only on people but also on animals, especially (see Csikszentmihalyi 2004: 140-141). ${ }^{17}$ Although his predictions were so accurate or unsettling that ordinary people preferred not to hear them, Liezi had developed a taste for magical practices and was enraptured. Acting as a disciple in this story, even though referred to as " $z i$ 子," ${ }^{18}$ Liezi plainly informs Calabash that he has found a better master: "Master, once I thought that your Way was the highest, but there is another which is higher still." ${ }^{19}$ Liezi's opinion may not have left Calabash totally unconcerned: you became a master by the appreciation of disciples, who temporarily studied under you. The more followers somebody attracted, the greater one's fame as a master was. ${ }^{20}$ The lack of any institutional framework to determine standards of quality and mediate rivalries no doubt contributed to the early masters' sensitivity about their reputations (see footnote 10). One consequence of this sensitivity is that in the Zhuangzi, master and disciple are rarely entirely isolated at teaching moments: frequently at least one other master is involved in the lesson, either because they go to visit him together, send disciples to him, refer to him, cite him, report on him, and most often evaluate him (see, for example, Zhuangzi 2 XII, 5 III, 6 VIII, 7 II, 7 V, 12 V, 12 X, 12 XI, 14 IV, 19 III, 19 IV, 21 I, 21 II, 21 IV, 22 I, 23 I, 28 V and 31 I). Conversations about masters therefore take an important place in the educational process: a narrative chain of masters is thereby formed, discussing one another and apparently masterful in their handling of the competition between them.

\footnotetext{
${ }^{16}$ For a similar reading of the Upanishads, focusing on the formal features of its teachings, see Black 2007. He distinguishes between four types of dialogical partners, four different social situations, and three narrative components (Black 2007: 18-19).

${ }^{17}$ For views on physiognomy in ancient Greece, see Boys-Stones 2007: 22-33.

18 The book ascribed to LIE Yukou 列禦寇 as a master is the Liezi. For more information, see Graham 1990.

${ }^{19}$ In Zhuangzi 12 XI Zigong enthusiastically tells his own pupils that he has discovered a superior master, going on to inform his own master, Confucius, of the fact with just as much enthusiasm. But Confucius disagrees.

${ }^{20}$ Commenting on the dialogue with Liezi and Master Calabash, Jean François Billeter remarks that "les compatriotes de Tchouang-tseu ont gardé jusqu'à ce jour un goût très vif pour la hiérarchie et les joutes dans lesquelles se décide qui vont dominer. Il leur importe de toujours savoir à qui revient le premier rôle" (see Billeter 2004b: 33).
} 
A second and related characteristic of Zhuangzi's masters is that their status often changes in the course of the story. In the fragment under consideration there is a gradual shift through four meetings. The shaman comes to visit Calabash full of selfconfidence and foretells his imminent death on the basis of his appearance. The next day, still brimming with self-confidence, he ascribes Calabash's apparent recovery to his own good influence. The third day he is troubled, but attributes this to his patient: Calabash is out of balance, but the shaman promises to return as soon as this is resolved. But the last day he flees, losing the status of potential master in Liezi's eyes. In this story the real master remains securely on his pedestal: Calabash emerges from the confrontation a clear winner. This is not always the case in the Zhuangzi: more than once the master discovers in the course of conversation that he has much to learn from his disciple. Famous in this regard is the story in which Confucius wants to become YAN Hui's disciple in "sitting and forgetting," or when he lectures Laozi about various great virtues, soon discovering the latter to be his better. ${ }^{21}$ Another example of role-shifting - and even more of the evaluation of masters - is the scene in which Toeless Nuncle Hill stumps off to visit Confucius. The amputated toes show the master that the visitor was once punished as a criminal, so he regards him as a lost cause. Toeless's response is:

It is only because I didn't know to do my best and was heedless of my body that I lost my foot. In coming to you, I am still possessed of something more precious than my feet and that is why I am doing my best to preserve it whole. There is nothing that heaven does not cover; there is nothing that earth does not carry. I thought of you as heaven and earth, sir. How could I have expected that you would treat me like this! (Zhuangzi 5 III)

Confucius realizes his error, shows willingness to teach Toeless, and even recommends him to his own pupils. Toeless, for his part, tells Laozi about the encounter, and together they conclude that Confucius has suffered a worse amputation than Toeless through his desire for reputation and fame.

A third feature of the characters, both masters and disciples (to the extent they can be distinguished), is that they are fictitious. Even when they are mythological emperors, historical rulers and ministers, or famous personalities such as Laozi and Confucius, ${ }^{22}$ it is clear that the author uses them as characters in invented dialogues, without suggesting that these conversations ever really took place. Usually the narrator makes no effort to attribute his ideas to well-known figures, and gives his characters invented names, in this instance Master Calabash or Gourd (Huzi 噎子). Other masters have-mostly in Victor Mair's translation-names as Nuncle Scattered, Nuncle Slippery, Uncle Obscure Nobody, Scattered Apart, Master Broadly Complete, Dumb Nonaction, Nonbeginning, Resplendent Light, Nonexistent Existence, Knowledge, Mad Stammerer, Doubtless Countenance, Regulate Firm, Countenance Complete, Prodigal Northpalace, Sir High, Vast Ignorance, Anonymous, Woman Hunchback, Infinity, Nonaction..., all rather harmless, odd figures. But Zhuangzi's contemporaries would have found some of his masters genuinely

\footnotetext{
${ }^{21}$ The former in 6IX, the latter in 14 VI. See also 12 VI and 24 III.

${ }^{22}$ On the conversations between Laozi and Confucius in the Zhuangzi, see McCraw 2010: 35-37 and Defoort 2007.
} 
objectionable, such as the ill and the mutilated, children and women, or craftsmen from the lowest occupations. The mutilated were generally former criminals who could be recognized by the amputation of a body part. They appear under such names as Shushan Toeless, Lipless or Clubfoot.

This choice of figures finally brings us to a fourth characteristic of the masters: they are empty, like a dried gourd or calabash used as water jug. The emptiness of Liezi's master is also apparent from the story: according to Calabash, Liezi went out into the world with insufficient attunement to the Way and too much self-confidence- he was too full - so that his face was easily read. The astute shaman had been able to "read" him, which made a great impression on Liezi. But greater attunement and less confidence on his side would have been better. ${ }^{23}$ Calabash therefore challenges the shaman to try his art on him: "Try bringing him here and let him take a look at me." While no words are exchanged between the two masters, the shaman's self-confidence melts away like snow in the sun when he is confronted four times with Calabash's ever more unreadable countenance, which is said to be "in emptiness intertwined" but also like water "surging up" and "ebbing away."

That other masters are also empty and inscrutable can be seen from such invented names as Uncle Obscure Nobody, Dumb Nonaction, Wearcoat, and Nonexistent Existence. The most remarkable example is probably a conversation-if it can be called such — between Resplendent Light and master Nonexistent Existence (wu you 無有):

Resplendent Light asked Nonexistent Existence: "Master, do you exist or do you not exist?" Since Nonexistent Existence did not respond to him, he did not get any answer; he intently looked at the other's appearance, sunken and hollow. For a whole day, he looked at him but did not see, listened to him but did not hear, groped for him but did not grasp. He said: "The ultimate! Who could attain this! I am able to let exist something nonexistent but not to not let it exist. As for not letting exist something existent, how could I attain this?" (Zhuangzi $22 \mathrm{XI}$ )

The disciple seems to have been granted a deep insight by a master who did not even reply to him, and who in all likelihood was not even there, as his name suggests. From the disciple's name, Resplendent Light, we can assume that he is fast and ungraspable: if anyone, he can bring things into existence by making them visible, but not things that appear to be totally nonexistent; nor can he make the visible things disappear. The master whom he thinks to be addressing seems to be even more subtle and ungraspable: he exists as nonexistence, which amounts to not existing at all, at least in the eyes of Resplendent Light. Such emptiness or absence illustrates an essential aspect of education, namely that despite all the guidance, help, and instructions one can get, teaching is never simply passing on expertise from one person to another. It is also, paradoxically and perhaps more importantly, allowing the student to discover what the master was not able to teach. There has to be a blind spot on the side of the master, an "ignorance," as Jacques Rancière puts it-an absence of content, some degree of incapacity or unavailability toward the student-for the

\footnotetext{
$\overline{{ }^{23} \text { For a more extensive fragment }}$ on the art of and resistance to physiognomy, see 24 VIII.
} 
teaching event to be more powerful than a mere transmission of knowledge or skills (Rancière 1995).

To conclude, the nature of the master-important yet changeable, fictitious, and empty - is an aspect of the form of education, not of its content. Plenty of stories show that the status of being a master was one of Zhuangzi's central preoccupations. Every one of his masters is a self-assured figure, but this is independent of his status, which is uncertain and changeable. The master's appearance as empty or ephemeral, and even nonexistent, not only confirms the uncertainty about the status of a master but also positively stresses his absence: a good master is at least to some extent provocatively and appealingly unavailable to the disciple who asks for instruction. These formal aspects of the teaching scenes seem to be crucial for Zhuangzi, at least as important as the ideas that are sometimes expressed in the dialogues.

\section{The Course of Instruction}

The second formal aspect of the teaching scenes relates to the course of instruction, to be discussed here in four consecutive steps, which are not always very distinct: (1) What is the setting in which the scene takes place? (2) How is the conversation initiated? (3) How does the master react? (4) What is the effect on the disciple?

First, the setting of an exchange covers such questions as: Where does this take place? Who goes to whom? How does the event come about? In the meetings between the shaman, Liezi, and Calabash, for instance, no movement is ascribed to the last: the shaman enters and exits, comes and goes, finally fleeing in haste, while Liezi is an intermediate between the two. Calabash, however, simply is there: he is visited, invites (through his disciple), explains or commands, and apparently does not budge. He remains unmoved while others move around him: toward or away from him, with increasing speed, until the shaman disappears for good and Liezi finally finds rest at his home. ${ }^{24}$ Generally in the Zhuangzi the disciple comes to the master, and very occasionally that pupil is even a king, which naturally increases the master's prestige. $^{25}$ This unmoving position taken by many masters in the Zhuangzi is analogous to that of the ideal ruler surrounded by active subordinates, the pole star amidst its celestial constellations.

Other stories make clear that Zhuangzi's masters do not literally sit still, but nevertheless remain unmoved or uninterested. Not awaiting a disciple's arrival, they are engaged in some action: one might be fishing, another feeding a cow, ploughing land, catching cicadas, slaughtering an ox, felling trees, carving wood, playing the lute, or simply having fun. ${ }^{26}$ The most astonishing is the master who is hopping along slapping his buttocks when addressed by a disciple.

\footnotetext{
$\overline{24}$ The shaman too brings others into motion: he chases away the common folk and attracts Liezi. But he himself is no match for Calabash.

${ }^{25}$ For the disciple going to a master, see, for example, Zhuangzi 4 I, 4 II, 4 III and 6 IV. For the ruler acting as disciple, see, for example, Zhuangzi 12 VI, and also King Wenhui visiting butcher Ding (Zhuangi 3 II). For an analysis of that fragment, see e.g. Graziani 2006: Ch. 1.

${ }^{26}$ For these actions, see, for example, Zhuangzi 3 II, 4 IV, 12 VII, 17 III, 19 III, 19 IX, 28 V, 21 II, and 31 I.
} 
Cloud General was travelling (you 遊) for fun to the east when he passed by an offshoot of a whirlwind and bumped into Vast Ignorance. Vast Ignorance was just at the moment having fun slapping his thighs and hopping about like a sparrow. Seeing him, Cloud General came to a sudden stop and stood there reverentially. "Who are you, old man?" he asked. "What are you doing?" Vast Ignorance replied, as he kept on slapping his thighs and hopping like a sparrow: "I am having fun (you 遊)." (Zhuangzi $11 \mathrm{~V}$ )

In the physical sense, Vast Ignorance is clearly moving, but like Calabash he is unmoved: he is fully engaged by what he is doing, in this case having fun or rambling around (you). This opening passage teaches us something else about the setting of the teaching moments, namely regarding the attitude of the disciple: unlike Liezi with Calabash, Cloud General is not a regular disciple, does not search for the master, but happens upon him while wandering around. Like Vast Ignorance, he too was you-ing. ${ }^{27}$

This last fragment also brings us to the second step of instruction, namely the initiation of the dialogue. Undeterred by the strange behavior of Vast Ignorance on the ground below him, Cloud General asks his advice about a serious problem:

"I want to ask a question," said Cloud General. "Pshaw!" said Vast Ignorance looking up at him. Cloud General said: "The breath of heaven is out of harmony, the breath of earth is in disarray, the six types of breath do not blend properly, the four seasons are out of rhythm. Now I would like to blend the essences of the six breaths in order to foster all living creatures. How should I go about it?" (Zhuangzi $11 \mathrm{~V}$ )

This passage is fairly typical of the Zhuangzi in that one person seeks another's advice, usually not with a purely speculative question. ${ }^{28}$ Most come with a practical request, often about political skills ${ }^{29}$ or the art of longevity, or even a combination of both-how do I save my skin in politics? Others want to be taught wood carving, ox cutting, archery, cicada catching, or making a set of bells (see, for example, Zhuangzi 3 II, 4 I, 6 IV, 19 III, 19 IX, 20 III, and 21 IX). While seeking instruction in a skill, the disciple sometimes asks the master's view of particular events or sayings, his explanation for the success of other masters, ${ }^{30}$ or elucidation on specific actions or inaction (see 2 I, 2 XIII and 4 IV). Usually when somebody wants to learn something from someone, he will give a clear token of respect, but does not always pose a question or make a request. A disciple might place himself under someone's tutorship without immediately engaging in conversation, but by following the master, imitating

\footnotetext{
${ }^{27}$ This pattern is found several times in the Zhuangzi and somewhat confirms the indeterminacy of the status of being a master. In this case the disciple is probably no more than a strong wind: Cloud General passes over the offshoot of a whirlwind (or the branches of a tree, in an adapted reading), and the master looks up at him. For other incidental moments of instruction, see, for example, Zhuangzi 12 XII, 19 III, 22 I, 27 VII, and 32 I.

${ }^{28}$ For somewhat more speculative questions, see, for example, Zhuangzi 2 XI, 11 IV, 22 VI, and 22 X.

${ }^{29}$ For political advice, see, for example, Zhuangzi 4 I, 4 II, 7 III, 7 IV, 12 XII, and 13 III.

${ }^{30}$ Chapter 5 in particular contains many explanations of the attractions of other (mutilated or ugly) masters. See, for example, Zhuangzi 5 I. In fragment 5 IV the erotic attraction of Nag the Hump, ugly enough to terrify all under heaven, is reminiscent of the erotic attraction of (the very ugly) Socrates on the youth of Athens and, more generally, of the intertwinement of eroticism and teaching, as argued by George Steiner (see Steiner 2003: 25-26, 140).
} 
him, hanging around, or simply experiencing his beneficial influence. We know, for instance, that Liezi is a disciple of Calabash, but he asks him no questions (at least not in this story) and it is not clear what his ambitions are. His enthusiasm for the shaman suggests that he wants to learn how to foretell the future, but this is nowhere stated in so many words.

A third step in the instruction scenes is the master's initial response. Calabash is somewhat critical of Liezi: "With you I have touched upon the surface pattern but not yet upon the substance. Have you really grasped the Way?" With a rhetorical question, he softly rebukes his disciple for over-eagerness combined with limited familiarity with the Way. Many masters are much more negative in their initial response: some seek to avoid the conversation by disparaging either themselves or their questioner. Often, a master will declare his own ignorance or lack of ability, like Vast Ignorance when faced with a weighty question on the ordering of nature: "While slapping his thighs and hopping like a sparrow, he looked down again and said 'I don't know, I don't know!'” (Zhuangzi $11 \mathrm{~V}$ ), a reply not entirely surprising, coming from somebody who is hopping along slapping his thighs. Sometimes negative responses are dismaying and discouraging. For example, to Skyroot's question about what should be done with the world, Anonymous replies: "Go away! You are a base fellow. Why ask such an unpleasant question?” (Zhuangzi 7 III). Some of Zhuangzi's masters seem to be the ancient Chinese counterpart of the unfriendly but apparently very appealing Dr. House: "Enough! Don't talk about it!" (Zhaungzi 7 III) and "Away with you!" (Zhuangzi 12 VI). These last two reactions are, admittedly, from masters (a carpenter and a border warden) who are busy working, absorbed by their own occupation. But the negative response can also be caused by the questioner's unsuitability, at least in the master's eyes. When somebody turns to Woman Hunchback to learn the Way, she sounds genuinely indignant: “Oh, no! You can't. You are not the person for it" and then goes on to recount the story of someone who did have a talent for it, even more so than she did (see 6 IV). ${ }^{31}$ Sometimes masters try to put their bad impression of a potential disciple into words: "You have a supercilious and haughty look" (Zhuangzi 27 VII) or "Get rid of your pompous attitude and your knowing look" (Zhuangzi $26 \mathrm{~V}$ ). Laozi seems to be an expert in physiognomy, when he explains what makes a would-be disciple unsuitable:

Your appearance is haughty, your look aggressive, your forehead is protruding, your mouth is snarly, your demeanor is self-righteous. You are like a horse restrained by its tether... You are inquisitorial and judgmental. Your knowledge is cunning and your gaze is overbearing. All of this invites mistrust. (Zhuangzi $13 \mathrm{~V}$ )

The questioner's lack of aptitude is written on his face: it has more to do with his appearance and behavior than with the opinions he holds, although these too play their part. Unsuitability is not entirely congenital but can also be caused-how else? - by the bad influence of other masters. Somebody who had previously learned "to dedicate

\footnotetext{
${ }^{31}$ The same expression "You are the wrong person 非其人也” was also used in the context of a doctor (YANG Zhongqian) rejecting a disciple (Gongsun Guang). See Shiji: Ch. 105 ("Biography of Bian Que and CHunYu Yi” quoted by Harper 1996: 59). The dialogues recorded by CHUNYU Yi in this chapter contain several formal similarities to the instruction dialogues in the Zhuangzi.
} 
himself to humaneness and righteousness, and speak clearly about right and wrong" is driven away by his new master as an irredeemably mutilated know-it-all:

“Then why have you come here?” asked XU You. "Yao has already tattooed you with humaneness and righteousness and lopped off your nose with right and wrong. How will you be able to wander on the path of untroubled and untrammeled evolution?" (Zhuangzi 6 VIII)

Besides a derogatory response, questioners are sometimes met with silence. Calabash says nothing, but apparently does something, at least something visible to the shaman, if not to Liezi. This silent attitude has parallels in many other scenes of instruction, even though strictly speaking the shaman here is no disciple. In one story, a scholar comes to visit Laozi in order to question him; he has made a long journey, and is shocked by the master's careless attitude toward the food that lies in heaps in front of him. Laozi, however, says nothing, makes no reaction, and the scholar leaves. The next day he is back again, saying that, to his own amazement, his anger has simply dissipated (Zhuangzi $13 \mathrm{~V}$ ).

The initial response of the master generally elicits something from the disciple that makes the master think it worthwhile to provide at least a modicum of advice or explanation - the content of the instruction, to which we turn later (part 5). Then follows, in a final step, the felicitous result of the teaching event, sometimes years after the dialogue takes place and not always what the disciple had expected. Liezi had been fascinated by the shaman's power of prediction; but after four days acting as go-between for the shaman and Calabash, and having listened to them, he "believed that he himself had not yet begun to learn." While this realization is presented as crucial for his life, no further explanation is given: What has he actually come to understand? And is he right? Can he prove it? Such questions are not treated in detail here, nor elsewhere in the text. But the teaching seems to pervade the rest of Liezi's life. We see how he goes on living: as a recluse, doing the strangest things: "He cooked for his wife and fed the pigs as though feeding humans." His whole attitude seems to have changed: "From his work he kept aloof; and from a polished gem he returned to be an un-carved block. In one piece, alone with his body, he stood there. In the midst of entanglement he remained sealed, and in this oneness he ended his life." The shaman also undergoes a change: we do not know what he thinks, we can surmise how he feels, but we see what he does: barely has his fourth meeting with Calabash begun, when he flees headlong from his presence. This combination is not uncommon in the Zhuangzi: we read little of what a disciple comes to think, more about how he feels, and most about what he does. ${ }^{32}$

Disciples are sometimes enthusiastic about what they have learned and express their admiration in words of praise or awe (which occasionally earns them a ticking off). One smiles, another relaxes, and as we have seen, one scholar loses his anger without Laozi even speaking a word. There is even an example of one falling asleep while receiving instruction: "Before [Wearcoat] had finished speaking, Gnaw Gap had fallen fast asleep. Wearcoat was greatly pleased and went away singing," launching into a verse in praise of the sleeper (Zhuangzi 22 III). Nodding off is

\footnotetext{
$\overline{32}$ Gongsun Long, a well-known orator who brought a problem to the master, was sent away: "Mouth agape and tongue-tied, he fled in consternation" (Zhuangzi 17 IV).
} 
unlikely to have been either the disciple's intention (he had a question about the Way, no trouble falling asleep) or the master's, but the latter is nevertheless exceptionally pleased with the result. The shaman perhaps congratulated himself on his intoxicating influence on Liezi, but for the author this is also a sign of his weakness: in the Zhuangzi masters deny wanting any control over their influence or appeal, lament it even, or are reproved for it by others. ${ }^{33}$

These four steps confirm the ambiguity not only of mastership but also of instruction: it is not always clear what the learner expects, nor what the master conveys; neither of them works very hard toward a supposed outcome, especially not the master. Learners learn while teachers do not teach. Like Melville's wellknown Bartleby, Zhuangzi's masters simply "would prefer not to," without giving good reason or strong argument. ${ }^{34}$ A master's unwillingness to teach can be instructive, because it shows him thoroughly absorbed by something and therefore not totally available to the disciple. From the master's indifferent or negative response until the often unexpected but nevertheless applauded result, there is sometimes a stretch of time reaching years beyond the actual teaching event. This shows that for Zhuangzi, what exactly the result is of one's teaching and when a disciple fully appreciates it cannot be easily determined, and certainly not in a routine manner. ${ }^{35}$

Thus far we have not yet touched upon those lines that are usually favored in philosophical interpretations. But I believe that by exclusively focusing on the formal properties of the instruction scenes we have hit some central insights viewing learning as a somewhat paradoxical and uncontrollable event. Taking these cues from the formal aspects of the Zhuangzi dialogues as the core of our understanding and their content as supportive evidence, we now turn to the ideas purveyed in the Calabash story.

\section{The Content of Calabash's Teaching}

In the formal analysis of the four steps of instruction we went straight from the third step (the master's initial negative reaction) to the fourth (the ultimate effect on the disciple, sometimes years after the actual meeting). Between these two there is generally a moment when explanation or advice is offered concerning nature, the Way, the cosmos, humanity, energy, and so forth-perfect material for a philosophy course. This is the point where most philosophically trained readers will probably become alert, look for coherent reflections, and bring in various theories, debates, philosophers, and-isms. But that approach is not really suggested by the nature of the sources, in this case the instruction dialogues in the Zhuangzi. First of all, speculative

\footnotetext{
${ }_{33}^{33}$ There is a story about Liezi, who, as a master, is not able to control people's attraction to and adoration for him (32I). See also Billeter 2004b: 29-31.

${ }^{34}$ There are many ways in which Zhuangzi's masters could be compared with the well-known figure in Herman Melville's (1966) "Bartleby the Scrivener": Bartleby is always calm and self-possessed, never agitated or angry, he has a mild and firm voice, inspires unbounded confidence and a strange effect, so that his boss moves to and from him, while he simply stays where he is (until others remove him by force).

${ }^{35}$ Teaching evaluations immediately following a class are increasingly used at universities. The evaluations and memories of alumni many years after their college education are usually very different and also less predictable. What has inspired them often turns out to be what current didactic evaluations would consider deficiencies of the teachers.
} 
ideas take up only a minor part in the whole event, suggesting that the content does not constitute the crucial message. While ideas certainly play a role in the learning process, they are less important than the visible change that the learner often unexpectedly experiences. Moreover, the disciple usually does not ask a theoretical question, the master does not convey a clear opinion, and the final outcome is not presented as a consistent insight. The message is generally as opaque as the form: in the teaching scenes it tends to be short and fragmentary, allegorical or poetic, obscure and filled with questions. These incoherent and unsystematic ideas are not shortcomings to be overcome by a charitable interpretation; they rather belong to a vague but persistent intuition on teaching pervading the Zhuangzi.

The content of the Calabash story is a fourfold explanation of the shaman's reactions to Liezi's master. Calabash speaks of germs, troubled water, the ebb and flow of the tides, and the life energy that he keeps in balance. We can interpret these images in terms of a well-attested underlying ontology that came into existence around the 4th century BCE, in which qi 氣 (vapor, pneuma, breath, vital energy) was considered the omnipresent, pervasive basic stuff in the world. This ontology probably originated from the interactions between philosophers and technical specialists in hygiene, cooking, ritual, medicine, or physiognomy. This emerging view can be summarized as follows: qi had two important characteristics. First, it was considered to have various gradations of subtlety, like one and the same material that can manifest as solid ice, fluid water, or volatile steam. Second, it was not static but followed an inherent order, like water flowing down and steam going up. In combination, these two characteristics lead to a world that not only shows spontaneous orderly motion - the Way (dào 道) of the heavenly bodies, the seasons, day and night, youth and age, life and death, etc.- - but that does so in more or less visible ways, depending on the subtlety of the things concerned. Everything that grows first manifests itself at the most subtle level, emerging from a dark, undivided chaos. While the general run of humanity only becomes aware of events when they emerge in their most visible form (like a lump of ice), a perceptive few can observe them already in or even before their volatile condition. A sagely physician can smell a disease before anyone has yet felt its effects; a wise counselor prevents a war before the king suspects any danger. Sagely, influential people can, moreover, exercise power over realities that are not yet even perceived by others. This view, with on the one hand a confidence in orderly motion, and on the other a fascination with subtle distinction emerging from chaos, is gradually made explicit and largely shared by many masters. One who wishes efficiency can attain it by adapting to the beneficial workings of nature at the earliest, obscure, improbably subtle but powerful level, where everything is permeated by scents, sounds, savors, spirits, and all sorts of hardly visible influences. ${ }^{36}$

This view of the cosmos seems to underlie the content of our story. There are important differences of degree: the shaman sees things that others cannot see and as a result is both shunned and lauded. He pervasively influences others one way or another: most people are scared away, but Liezi's heart is intoxicated, just as a scent or music can insensibly take possession of a person. The shaman can foretell the future with astounding accuracy but cannot influence the course of events, even

\footnotetext{
${ }^{36}$ For other presentations of this emerging ontology, see Harper 1996: 77-78 and Lewis 2006: 21-26.
} 
though he claims credit for Calabash's apparent recovery. Calabash, in contrast, seems to exert control at a level that the shaman can only perceive, and to which most mortals, like Liezi, are utterly oblivious. At each of the four visits, Calabash is able to assume a different appearance, the qi getting subtler and more amorphous each time. First he shows "the patterns of the earth, like germs not moving but not stopping," sprouts of life on the verge of becoming visible. As Calabash restrains his life force, "holds down the trigger of power," the shaman mistakenly identifies this as a sign of eminent death. The next day he shows the shaman "the heavenly clod, where names and substances do not enter," a level that precedes germination, where things are not yet distinct and therefore not yet named. At that level, full of power and life force, the breath proceeds from the most profound depths. The day after that he shows his guest "the supreme vastness where nothing wins out," the dark point around which everything turns and where even contradictions are not yet apparent, so that there is no distinction between heaven and earth. As the shaman is only capable of reading differences, subtle though they be, he is simply bewildered. On the fourth day Calabash has withdrawn to his ancestor, before he "had begun to come out." He explains to Liezi: "I was in emptiness intertwined with it, not knowing who is who. Now he thought that I was ebbing away, and then he thought that I was surging up."

These four steps of increasing formlessness are not entirely transparent in the Chinese text, but there is clearly a sense of decreasing distinctness combined with growing power. The imagery of water serves relatively well for the expression of not only this subtlety and indistinctness, but also of the inherent and beneficent movement of nature, the second major characteristic of the qi-ontology. That Calabash refers to water on the third day, after the stages of earth and heaven, suggests that the chaos of water precedes the separation of heaven and earth. ${ }^{37}$ What the shaman finally flees from is not the person of Calabash himself but what flows in him to the natural but awesome rhythm of the tides. Instruction in stages is typical of many teaching scenes, just like the consecutive days on which Calabash receives the same visitor over and again, letting him in and out, through a rhythmical motion, drawn in on a current and then driven back on a swell. That is how deep Calabash breathes.

\section{Zhuangzi's Instructions}

The content of the Calabash story can thus be reconstructed in terms of an emerging ontology, but that is not its main point, nor is it the focus of my "anthropological" reading. Like other instructions in the Zhuangzi, it is fragmentary, both in content and in form. How does this fragmentation relate to the implied preference for dark indistinctness and reliance on the natural flow of $q i$ ? What sort of teaching model is promoted through these stories? It is perhaps easier to determine what sort it is not.

First, although Calabash expounds some views to Liezi and the latter treats him as a master, the four short and obscure explanations are miles away from what is nowadays usually considered a well managed teaching event, let alone a university course in philosophy. The scenes resemble more the personal classes of the classically

\footnotetext{
$\overline{37}$ For this imagery of water in early Chinese thought, see the Guodian manuscript “Taiyi Sheng Shui 太一生水” (Taiyi Generates Water) and, more generally, see Allan 1997.
} 
trained scholar and the secret healer who feature in Elisabeth Hsu's research, or perhaps also the instances of "care for oneself" in early European philosophy. The instructions are indeed not foremost about transmitting a theory or conviction, not even "knowledge of oneself," the focus being on attitudes and skills (knowing how) rather than knowledge (knowing that).

But even though these stories clearly celebrate the transformation in practice and experience brought about by the strange meetings between masters and disciples, they also seem to mock pedantic scholars and confident healers. ${ }^{38}$ Zhuangzi knew well the health specialists and physicists, $\mathrm{Ru}$ and Mo masters, future-tellers, or other teachers to whom his contemporaries went for advice or training. Calabash's descriptions show his familiarity with physiognomy and breathing techniques (the breath that starts from the heels), and their intertwinement with other techniques (the "trigger" as a launching mechanism, and the "balance" to weigh accurately). But for Zhuangzi, these various specialists were trying too hard and wanting too much, like the shaman predicting everybody's future. The teaching events are therefore also far away from the daily exercises and stringent discipline that Michel Foucault and Pierre Hadot describe in Cynic, Stoic, and Epicurean circles (Foucault 2001; Hadot 1987: 13-47). Many teaching dialogues do not seem to convey practical techniques any more than a moral code or philosophical system. The masters do not claim to offer an alternative option that can guarantee success in matters of health or politics. Others might distill a coherent philosophy or a life-stimulating technique from their words, but most Zhuangzi's masters resist any such urge.

But what then characterizes the intuition pervading the teaching dialogues? What sort of teaching does their form suggest? Zhuangzi's masters more than once emphasize that their skill is no technique ( $s h u$ 術), but something bigger, namely the Way (see e.g. 3II, 19IX, and 20III). In the competition between masters described above, this could be taken as an attempt to escape the rivalry of moralizing contemporaries and to stand above the zealous specialists of hygiene and health techniques. The story about Liezi and Calabash indeed breathes an air of rivalry, for instance in the art of physiognomy. But it is of a special type: Calabash makes no attempt to be more discerning than the shaman, seeking instead to become increasingly less readable to him. During four days Liezi fails to realize that his Master is taking no part in a competition of techniques or skills, even though Calabash is familiar with them. It is only after the disciple has chased the shaman and found nothing (or Nothing ${ }^{39}$ ) that Liezi realizes he will have to turn around: not only his steps while chasing the shaman, but also his life. In his zeal to convince the world and his eagerness to find a better Way, he has in fact failed to get the point. He wanted to learn more and more, amass skills, such as the ability to foretell the future, to "set the date within a year, a month, a week, or a day." But now he abandons these attempts, even stops visiting his master, cocoons himself in the darkness of his home, and undergoes the lingering effects of what happened during those four days. After three years he has lost his form, been transformed "from a polished gem" to "an un-carved block." Even the

\footnotetext{
$\overline{38}$ The long narrative in the chapter "Ingrained Opinions" (Ke Yi) ridicules various types of masters, including those of physical cultivation (Zhuangzi 15I). For Zhuangzi's criticism of contemporary specialists of ritual magic and cultivation exercises, see Puett 2003: 248-262.

${ }^{39}$ With Nothing, I mean the insight that within every good teacher there is also a necessary "absence of a teacher." See above the $4^{\text {th }}$ characteristic of the master.
} 
most fundamental human distinctions - at least according to his contemporaries escape him: those between man and woman (he cooks for his wife!) and between man and animal (he feeds pigs as though they were human).

Calabash's way of competing is thus by not adding capacities or doing better, but by retreating into a stage of inscrutable indistinctness where the pulse of nature takes over. This seems to increase his power. By emptying himself, he makes sure that nothing stands in the way of his life breath-no tensions or obstacles, no convictions or desires, no virtues or judgments. Zhuangzi's hero is generally someone who retreats, forgets, sleeps, sings, keeps silent, or wanders. He lives in the world of visible shapes, like the rest of us, but gently approaches them in their formless state, where they are not distinct from the rest, but are part of the breath that moves everything. To some extent the story confirms Hal Roth's ascription of apophatic inner cultivation practice to Zhuangzi, on the basis of narrative passages and some dialogues in the book. But the formal characteristics of the teaching events, more specifically the masters' noncooperation, unpredictability, and occasional absence, at the same time indicate a reluctance to rely on any type of training (see Roth 1999: 153-161). ${ }^{40}$

As opposed to his contemporaries, Zhuangzi's masters seem to have an intuition that gets lost as soon as one tries to turn it into a moral system or formal training. The teaching dialogues therefore contain at least a portion of anti-teaching in two important ways. First there is an appreciation of absence - the unavailability, nonchalance or resistance of the teacher to his or her teaching role. It alerts us to the fact that we influence our children and students in ways that are not all intended or planned, sometimes even most fruitfully when we fail to be model teachers. This sort of absence (lack, failure, reluctance, disinterest, incapacity) hidden at the core of the teacher not only forces the disciple to turn to himself, but also portrays a model who is himself absorbed by something else, be it cutting an ox, slapping his thighs, or doing research. Although teaching ideally involves care and concern for the student, the teacher's blind spot should also be acknowledged and cherished. The second aspect of anti-teaching shows, moreover, that this Zhuangzian attitude cannot be consciously adopted for the sake of being an inspiring teacher. Teaching concerns to a large extent a transmission of knowledge, insights, and skills, but the Zhuangzi stories remind us of the fact that it should also contain a measure of not teaching, letting go, un-doing, liberating, or undermining.... While Zhuangzi's masters may not have very specific educational intentions vis-à-vis the disciple, they do have some intentions, namely to notice the force and value of their energetic underflow, and to let it proceed without obstruction. Their training lays in removing obstacles, including those of fixed norms, elegant theories, clear judgments, good intentions, and efficient techniques. All such certainties ultimately impede the formless force that, powerfully but beyond our apprehension, flows within us.

But how does one train in not-training? ${ }^{41}$ Why is letting go and emptying oneself more worthwhile pursuing than other ideals? And how does one distinguish the beneficial life force from the other drives in one's body? There may not be final

\footnotetext{
${ }^{40} \mathrm{He}$ relates these practices to the "Inward Training" (Nei Ye) chapter in the Guanzi.

${ }^{41}$ This can be considered a central question in Chinese philosophy. See e.g. Slingerland 2003.
} 
answers, just as there is no clear educational setting or timetable for most of what we learn in life. As in Zhuangzi's dialogues, you might find only shards of answers if you meet the right person at the right time, somebody who sees something that had escaped your own attention, because he has more delicate perceptions - he smells, sees, feels or hears something in you. Or, perhaps even more effectively, somebody who turns away when you are desperate for an answer. The reluctant or unconscious master may unknowingly help you along the Way with a small intervention - an insult, a rejection, a verse, a story or just a moment's silence. And it may take years to notice its beneficent result.

Acknowledgments This paper was first presented at the international conference "What Is Philosophy?" at the University of Zurich (January 2011) and at a doctoral workshop at the University of Leuven (April 2011). I thank all the participants, Nicolas Standaert, and the anonymous reviewers of Dao for their useful comments.

\section{References}

Allan, Sarah. 1997. The Way of Water and Sprouts of Virtue. New York: SUNY Press.

Billeter, Jean François. 2004a. Leçons sur Tchouang-tseu. Paris: Editions Allia. 2004b. Etudes sur Tchouang-tseu. Paris: Editions Allia.

Billioud, Sébastien \& Joël Thoraval. 2007. "Jiaohua: The Confucian Revival in China as an Educative Project." China Perspectives 2007.4: 4-20.

2009. "Lijiao: The Return of Ceremonies Honouring Confucius in Mainland China." China Perspectives 2009.4: 82-100.

Black, Brian. 2007. The Character of the Self in Ancient India. Priests, Kings, and Women in the Early Upanishads. New York: SUNY Press.

Boys-Stones, George. 2007. "Physiognomy and Ancient Psychological Theory." In Seeing the Face, Seeing the Soul. Polemon's Physiognomy from Classical Antiquity to Medieval Islam. Ed. by Simon Swain, Oxford: Oxford University Press.

Csikszentmihalyi, Mark. 2001. "Confucius.” In The Rivers of Paradise: Moses, Buddha, Confucius, Jesus, and Muhammad as Religious Founders. Ed. by David Noel Freedman and Michael James McClymond. Grand Rapids: Eerdmans.

2004. Material Virtue: Ethics and the Body in Early China. Leiden: Brill.

Defoort, Carine. 2001. "Is There Such a Thing as Chinese Philosophy? Arguments of an Implicit Debate." Philosophy East and West 51.3: 393-413.

2006. "Is 'Chinese Philosophy' a Proper Name. A Response to Rein Raud.” Philosophy East and West 56.4: 625-660.

2007. "The Creation of Confucianism: Confucius in the Zhuangzi" (paper presented at the conference on "Confucianism as Religion," Leiden 23-25 May 2007).

Eno, Robert. 1990. The Confucian Creation of Heaven: Philosophy and the Defense of Ritual Mastery. New York: SUNY Press.

Feldman, Richard. 1998. "Charity, Principle of.” In Routledge Encyclopedia of Philosophy. 10 Vols. Ed. by Edward Craig. London/New York: Routlegde.

Foucault, Michel. 2001. L'herméneutique du sujet. Cours au Collège de France (1981-1982). Ed. by François Ewald, Frédéric Gros \& Alessandro Fontana. Paris: Gallimard. Translated by Graham Burchell as The Hermeneutics of the Subject: Lectures at the Collège de France, 1981-1982, New York: Palgrave-Macmillan, 2005.

Fu, Sinian 傅斯年. 2003. “The Forms of Writings of the Sources from the Warring States: A Brief Note 戰國 文籍中之篇式書體: 一個短記.” In Complete Works of FU Sinian 傅斯年全集, vol. III. Ed. by OUYANG Zhesheng. Changsha: Hunan Jiaoyu Chubanshe.

Graham, A.C. 1986. Chuang-tzu: The Inner Chapters. London: George Allen and Unwin. 1990. The Book of Lieh-tzu. A Classic of Tao. New York: Columbia University Press.

Graziani, Romain. 2006. Fictions philosophiques du Tchouang-tseu. Paris: Gallimard.

Hadot, Pierre. 1987. Exercices spirituels et philosophie antique. Paris: Études Augustiniennes. 
Harper, Donald. 1996. Early Chinese Medical Literature: The Mawangdui Medical Manuscripts. London \& New York: Kegan Paul International.

Hsu, Elisabeth. 1999. The Transmission of Chinese Medicine. Cambridge: Cambridge University Press.

Huang, Jinhong 黄錦鈜. 1983. A Zhuangzi Reading Text 莊子讀本. Taibei: San Min Publications.

Kohn, Livia, ed. 2000. Daoism Handbook. Leiden: Brill.

LaFargue, Michael, trans. 1992. The Tao of the Tao Te Ching. A Translation and Commentary. New York: SUNY Press.

Lee, Thomas, ed. 2000. Education in Traditional China: A History. Leiden: Brill.

Levi, Jean. 2006. Les Oeuvres de Maître Tchouang. Paris: Editions de l'Encyclopédie des Nuisances.

Lewis, Mark. 1999. Writing and Authority in Early China. Albany, NY: SUNY Press. 2006. The Flood Myths of Early China. NY: SUNY Press.

Liu, Xiaogan. 1994. Classifying the "Zhuangzi” Chapters. Michigan: University of Michigan.

Lloyd, Geoffrey and Nathan Sivin. 2002. The Way and the Word: Science and Medicine in Early China and Greece. New Haven and London: Yale University Press.

Mair, Victor, transl. 1994. Wandering on the Way. Early Taoist Tales and Parables of Chuang Tzu. New York/Toronto/London/Sydney: Bantam Books.

McCraw, David. 2010. Stratifying Zhuangzi: Rhyme and other Quantitative Evidence. Taipei: Academia Sinica.

Melville, Herman. 1966. "Bartleby the Scrivener.” In Four Novels. Belgrade: Prosveta.

Puett, Michael. 2003. "Nothing Can Overcome Heaven': The Notion of Spirit in the Zhuangzi.” In Hiding the World in the World. Uneven Discourses on the Zhuangzi. Ed. by Scott Cook. New York: SUNY Press.

Rancière, Jacques. 1995. Le maitre ignorant. Mesnil-sur-l'Estréé: Fayard.

Roth, Hal. 1991. "Who Compiled the Chuang Tzu?" In Chinese Texts and Philosophical Contexts. Ed. by H. Rosemont, Jr. La Salle: Open Court.

1999. Original Tao. Inward Training and the Foundations of Taoist Mysticism. New York: Columbia University Press.

Slingerland, Edward. 2003. Effortless Action. Wu-wei as Conceptual Metaphor and Spiritual Ideal in Early China. Oxford: Oxford University Press.

Steiner, George. 2003. Lessons of the Masters. Cambridge: Harvard University Press.

Thoraval, Joël. 2002. "Expérience confucéenne et discours philosophique." Perspectives Chinoises 71: 6483.

Watson, Burton. 1968. The Complete Works of Chuang Tzu. New York: Columbia University Press.

Wu, Kuang-ming. 1982. Chuang Tzu: World Philosopher at Play. New York: Crossroad. 